\title{
MODIFIED NATURAL ZEOLITE AND BENTONITE AS ADSORBENTS OF HEAVY METAL IONS FROM POLLUTED GROUNDWATER IN YOGYAKARTA URBAN ARE, INDONESIA
}

\author{
Bunchoeun Pich ${ }^{1}$, I Wayan Warmada*1 ${ }^{*}$ Heru Hendrayana ${ }^{1}$, and Tetsuro Yoneda ${ }^{2}$ \\ ${ }^{1}$ Department of Geological Engineering, Faculty of Engineering, Gadjah Mada University, Yogyakarta, Indonesia \\ ${ }^{2}$ Division of Solid Waste, Resources and Geo-Environmental Engineering, Graduate School of Engineering, Hokkaido University, \\ Sapporo, Japan
}

\begin{abstract}
Groundwater quality in Yogyakarta city has become the major concern due to the presence of heavy metals originated from batik home industries, slaughterhouses, and leather factories, especially in shallow groundwater. In response to the above problems, the naturally abundant zeolite and bentonite in Sidomulyo and Bandung areas were respectively sampled along with the metal-containing groundwater in Yogyakarta urban area for batch adsorption experiment. Before put into experiment, the zeolite and bentonite were characteristically investigated by means of XRD, SEM, chemical composition, and physical property analyses. Also, they were thermally activated to improve their qualities in terms of increase in CEC, whereas the groundwater was analyzed for heavy metal concentrations $(\mathrm{Cd}, \mathrm{Cr}, \mathrm{Cu}, \mathrm{Fe}, \mathrm{Zn})$ and its physical property. Five logarithmic amounts of this modified zeolite or bentonite were separately and incrementally introduced into the same three solutions of heavy metals. After the experiment, all the solutions were re-analyzed for the rest of heavy metals to figure out the optimum adsorption capacity of zeolite and bentonite. The outcomes of this experiment will be beneficial in enhancing the groundwater quality for consumptions in Yogyakarta city as well as other places in Indonesia, and will also imply the zeolite and bentonite in commercialization.
\end{abstract}

Keywords: zeolite, bentonite, groundwater, heavy metal, adsorption

${ }^{*}$ Corresponding author: I W. WARMADA, Department of Geological Engineering, Faculty of Engineering, Gadjah Mada University, Jl. Grafika 2 Yogyakarta, 55281, Indonesia. E-mail: warmada@yahoo.com

\section{Introduction}

Yogyakarta urban area is considered as a place facing groundwater problems. As a result of landuse development, the groundwater quality has been significantly deteriorating due to the human activities which lead to the groundwater pollution sources such as the oil stocks, batik home industries, slaughter houses, and leather factories. According to the previous researches of the graduate students (e.g. Keophousone, 2007; Huyen, 2007; Raksmey, 2007), the contaminants or pollutants namely heavy metals, nitrates, organic substances, coli-form bacteria, and viruses are mostly found in shallow groundwater; amongst these contaminants, the heavy metal ions such as lead $(0.32 \mathrm{mg} / \mathrm{l})$, chrome $(0.47 \mathrm{mg} / \mathrm{l})$, iron $(0.06 \mathrm{mg} / \mathrm{l})$, copper, cadmium, and zinc are the major concern of the locals. The researches have been conducted just to assess the groundwater contaminant loading potential (Keophousone, 2007), to model the groundwater flow (Huyen, 2007), and to map the groundwater vulnerability (Raksmey, 2007) in Yogyakarta urban area, not yet has any research on real groundwater remediation been done there.

In response to these groundwater problems, the natural zeolite (zeolitic tuff) which is abundant in the Sidomulyo area, Gunung Kidul Regency, Yogyakarta Special Province and natural bentonite (bentonitic tuff) which is mostly present in the Bandung area, Boyolali Regency, Central Java, Indonesia are utilized in this research as adsorbents, based on their appropriate characteristics resulted in the previous researches by using zeolite as an adsorbent (Prasetya et al., 2006) and a fertilizer (Idrus et 
al., 2006; Titisari et al., 2006), and using bentonite as an adsorbent (Vega et al., 2005) and a diarrhea healer (Titisari et al., 2007), to remove or adsorb the heavy metal ions from the groundwater in Yogyakarta urban area. The outcomes of groundwater treatment under the aid of rock-forming zeolite or bentonite will be beneficial in enhancing the quality of groundwater for the consumption in Yogyakarta city as well as in other places in Indonesia. Moreover, the experiment results will imply the quality of zeolite and bentonite in stimulating the development of their industrial applications.

\section{Methodology}

A total of 6 natural zeolite samples from the Sidomulyo area, Gedangsari district, Gunungkidul regency, Yogyakarta special province along with the totally 6 natural bentonite ones from the Bandung area, Wonosegoro district, Boyolali regency, central Java, Indonesia were analyzed in terms of mineralogical characteristics (XRD investigation and SEM observation), chemical composition analyses (major oxides), and physical property analyses (CEC and $\mathrm{pH})$. These Sidomulyo zeolitic tuffs and the Bandung bentonitic tuffs were investigated by the XRD equipment at the Geochemistry Laboratory, Geological Engineering Department, Faculty of Engineering, Gadjah Mada University, Indonesia. Also, they were observed by SEM equipment at the Quarter Geology Laboratory, Geology Survey Center, Bandung, Indonesia. The chemical composition analyses (ICP) were done in Canada, but the physical property (initial/un-activated CEC and $\mathrm{pH}$ ) were analyzed in the Chemical Engineering Department, Faculty of Engineering, Gadjah Mada University, Indonesia.

Moreover, these tuffs were thermally activated at the Geological Engineering Department, Faculty of Engineering, Gadjah Mada University, Indonesia in order to improve their qualities in terms of increase in CEC before put into the batch adsorption experiment with solution of heavy metal concentrations. Meanwhile, the metal-polluted groundwater sample was analyzed for initial concentrations of five heavy metals of case study, namely $\mathrm{Cd}, \mathrm{Cr}, \mathrm{Cu}, \mathrm{Fe}, \mathrm{Zn}$ at the Hydrology Laboratory, Geography Faculty, Gadjah Mada University, Indonesia and it was re-analyzed for their final/remaining concentrations after the experiment. The treatment of polluted groundwater itself by method of batch adsorption was done at the Geological Engineering Department, Faculty of Engineering, Gadjah Mada University, Indonesia. The results of the analyses and the experiment are beneficial in interpreting the characteristics and the adsorption capacity of the zeolite and bentonite and in enhancing the quality of groundwater in Yogyakarta urban area.

\section{Results}

\subsection{Characterization}

Physical Properties. The Sidomulyo zeolitic tuff (Figure 1) is predominantly composed of zeolite mineral and tuff. It is physically green in color, clastic-textural, coarse-fine, and grain-sized (Idrus et al., 2006), whereas the Bandung bentonitic tuff abundantly contains montmorillonite mineral and tuff. It is grayish-white in color, conchoidal-fractural, earthy-plastic when moistened, argillaceous-odorous when breathed upon (Titisari et al., 2006). In terms of physical property, the cation exchange capacities (CEC) of the Sidomulyo zeolitic tuff and the Bandung bentonitic tuff in the initial/un-activated condition are 44.4 mgr.eq. $\mathrm{Na}_{2} \mathrm{O} / 100$ gram zeolite and 20.0 mgr.eq. $\mathrm{Na}_{2} \mathrm{O} / 100$ gram bentonite, respectively.

Chemical Compositions. Due to the late result from Canada, the chemical compositions in terms of major oxides/elements of the Sidomulyo zeolitic tuff and the Bandung bentonitic tuff, however, can be expected based on the previous studies in the Gedangsari and Wonosegoro areas. Idrus et al. (2006) and Idrus et al. (2007) indicated, from geochemistry analysis, that the Sidomulyo zeolite (Gedangsari) is composed of $72 \mathrm{wt} \%$ of $\mathrm{SiO}_{2}, 9-11$ wt. $\%$ of $\mathrm{Al}_{2} \mathrm{O}_{3}, 1.6$ wt. $\% \mathrm{FeO}, 0.8-1.2$ wt. $\%$ of $\mathrm{MgO}$, $3.3-4.5$ wt. $\%$ of $\mathrm{CaO}, 1.1-1.5$ wt. $\%$ of $\mathrm{Na}_{2} \mathrm{O}, 0.7-1$ wt. $\%$ of $\mathrm{K}_{2} \mathrm{O}$, and 8 wt.\% of $\mathrm{H}_{2} \mathrm{O}$. Another study of Titisari et al. (2006) in the Gedangsari area revealed that the zeolitic tuff contains 53.27 wt.\% of $\mathrm{SiO}_{2}$, 11.12 wt. $\%$ of $\mathrm{Al}_{2} \mathrm{O}_{3}, 2.20$ wt. $\%$ of $\mathrm{K}_{2} \mathrm{O}, 3.17$ wt.\% of $\mathrm{Na}_{2} \mathrm{O}, 5.08$ wt. \% of $\mathrm{Fe}_{2} \mathrm{O}_{3}, 0.02$ wt.\% of $\mathrm{MnO}, 0.14$ wt.\%, and 3.17 wt.\% of CaO. As for the Wonosegoro, Titisari et al. (2007) showed that the bentonitic tuff is comprised of 53.92-62.98 wt.\% of $\mathrm{SiO}_{2}, 0.50-0.93$ wt. $\%$ of $\mathrm{TiO}_{2}, 15.17-21.58$ wt. $\%$ of $\mathrm{Al}_{2} \mathrm{O}_{3}, 0.40-3.17$ wt.\% of $\mathrm{FeO}, 2.81-4.28$ wt.\% of $\mathrm{Fe}_{2} \mathrm{O}_{3}, 0.03-0.13$ wt.\% of $\mathrm{MnO}, 1.47-2.32$ wt.\% of $\mathrm{MgO}, 1.44-3.84$ wt. $\%$ of $\mathrm{CaO}, 0.31-1.33$ wt. $\%$ of $\mathrm{Na}_{2} \mathrm{O}, 0.64-1.89$ wt. $\%$ of $\mathrm{K}_{2} \mathrm{O}$, and 3.59-7.66 wt. \% of $\mathrm{H}_{2} \mathrm{O}$.

XRD Analyses. The XRD analysis result shows that the Sidomulyo zeolitic tuff bears several types of minerals namely clinoptilolite-heulandite, mordenite, montmorillonite, quartz, plagioclase (albite), and orthoclase (Figure 2). This agrees with the result of Idrus et al. (2006) but it is just that, in this study, the clinoptilolite can be seen more than the mordenite which is opposite from that of Idrus et 

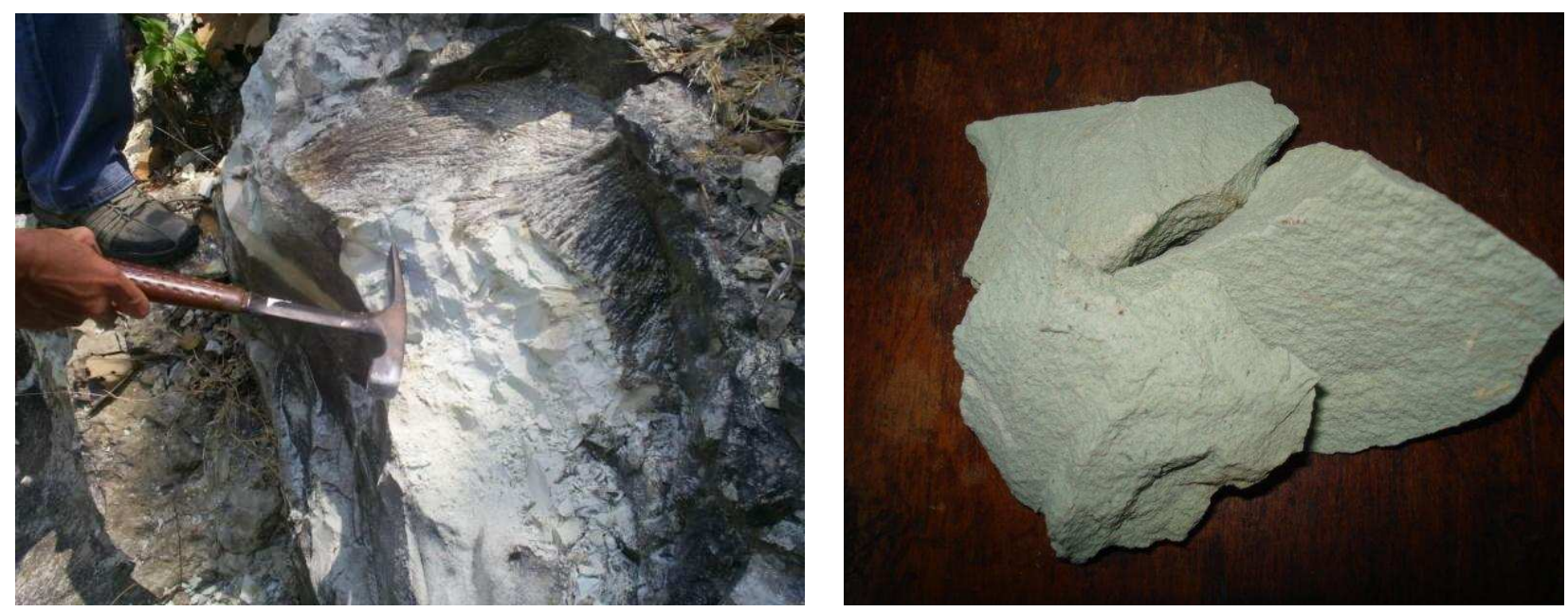

Figure 1: The surficial zeolitic and bentonitic tuff at the Sidomulyo area (Gunungkidul regency) and the Bandung area (Boyolali regency), respectively, Java Island

al. and this is maybe because of different locations of samplings. The Bandung bentonitic tuff from the XRD result displays the content of montmorillonite, clinoptilolite-heulandite, quartz, illite, kaolinite, chlorite, plagioclase (albite \& anorthite), and orthoclase. This also agrees with the findings of Titisari et al. (2006).

SEM Analyses. The SEM analysis results are late during this time. However, several results from the previous studies in the same areas could be used as references. The SEM results of Idrus et al. (2006) and of Titisari et al. (2006) exhibit the structural characteristics of the Gedangsari zeolite (Sidomulyo) and the Wonosegoro bentonite (Kedungbedah). From the photomicrograph of the Gedangsari zeolite, the tabular structure of clinoptilolite, the fibrous structure of mordenite, the webby structure of montmorillonite can be clearly recognized and identified. Regarding the Wonosegoro bentonite, the photomicrograph exposes the webby structure of montmorillonite, the blade structure of clinoptilolite, the hairy structure of illite, and the sheet structure of dickite. Also, volcanic glass altered to zeolite and clay minerals can be detected in the photomicrographs of the rocks. This can prove to the results of XRD analyses that the Sidomulyo rock and the Bandung rock are certainly the zeolitic tuff and the bentonitic tuff.

\subsection{Activation Process}

Referring to the previous researches of Idrus et al. (2006) and Titisari et al. (2007), the optimum condition for activation process is suggested at the heating temperature of $250{ }^{\circ} \mathrm{C}$ during 1 hour for the Sidomulyo zeolitic tuff and that of $300{ }^{\circ} \mathrm{C}$ dur- ing 1 hour for the Bandung bentonitic tuff. Following this, the CEC of the Sidomulyo zeolitic tuff and the Bandung bentonitic tuff are then increased to 65.3 mgr.eq. $\mathrm{Na}_{2} \mathrm{O} / 100$ gram zeolite and 28.6 mgr.eq. $\mathrm{Na}_{2} \mathrm{O} / 100$ gram bentonite, respectively.

\subsection{Groundwater Analyses}

With the equipment of AAS (atomic absorption spectrophotometer), the initial concentrations of heavy metals containing in the Yogyakarta urban area groundwater can be identified: $\mathrm{Cd}^{2+}=0.01$ ppm, $\mathrm{Cr}^{6+}=0.04 \mathrm{ppm}, \mathrm{Cu}^{2+}=0.14 \mathrm{ppm}, \mathrm{Fe}^{2,3+}$ $=0.02 \mathrm{ppm}$, and $\mathrm{Zn}^{2+}=0.11 \mathrm{ppm}$. Determined by $\mathrm{pH}$ meter, the groundwater sample has $\mathrm{pH}$ of 6.7. Comparing to the guideline of standard drinking water $(\mathrm{WHO})$, this kind of groundwater could give adverse impacts to health. For this reason, the groundwater is considered polluted and need to be treated.

\subsection{Adsorption Experiment}

\section{Materials}

1. Two minerals: modified zeolite and modified bentonite

2. Five heavy metals: $\mathrm{Cd}, \mathrm{Cr}, \mathrm{Cu}, \mathrm{Fe}, \mathrm{Zn}$ in a solution of 1 groundwater sample

3. Fifteen reaction glasses

\section{Limitations}

1. $250 \mathrm{ml}$ of solution of heavy metals

2. initial metal concentrations in solution are known 


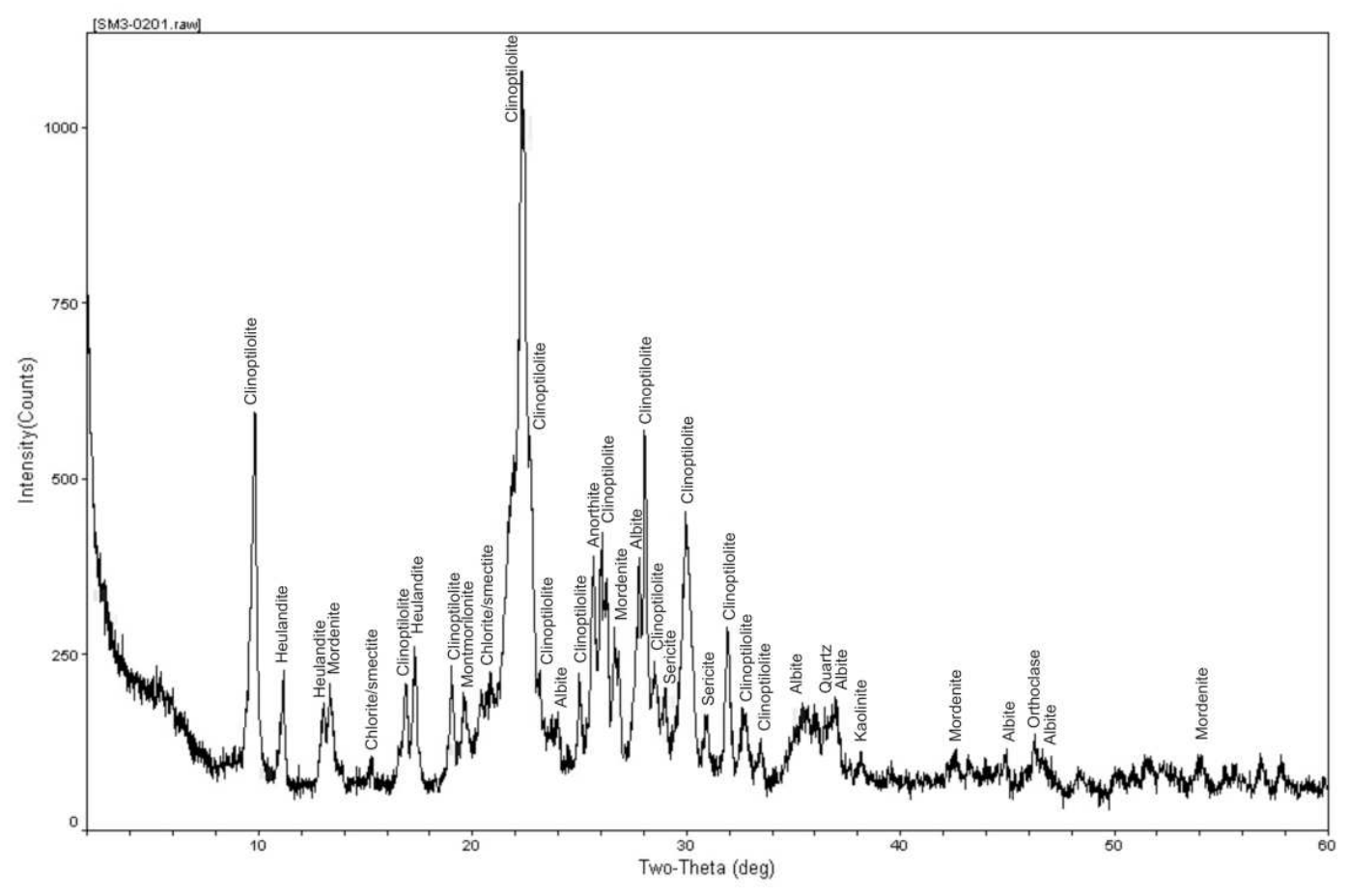

Gadjah Mada University

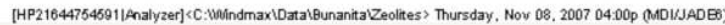

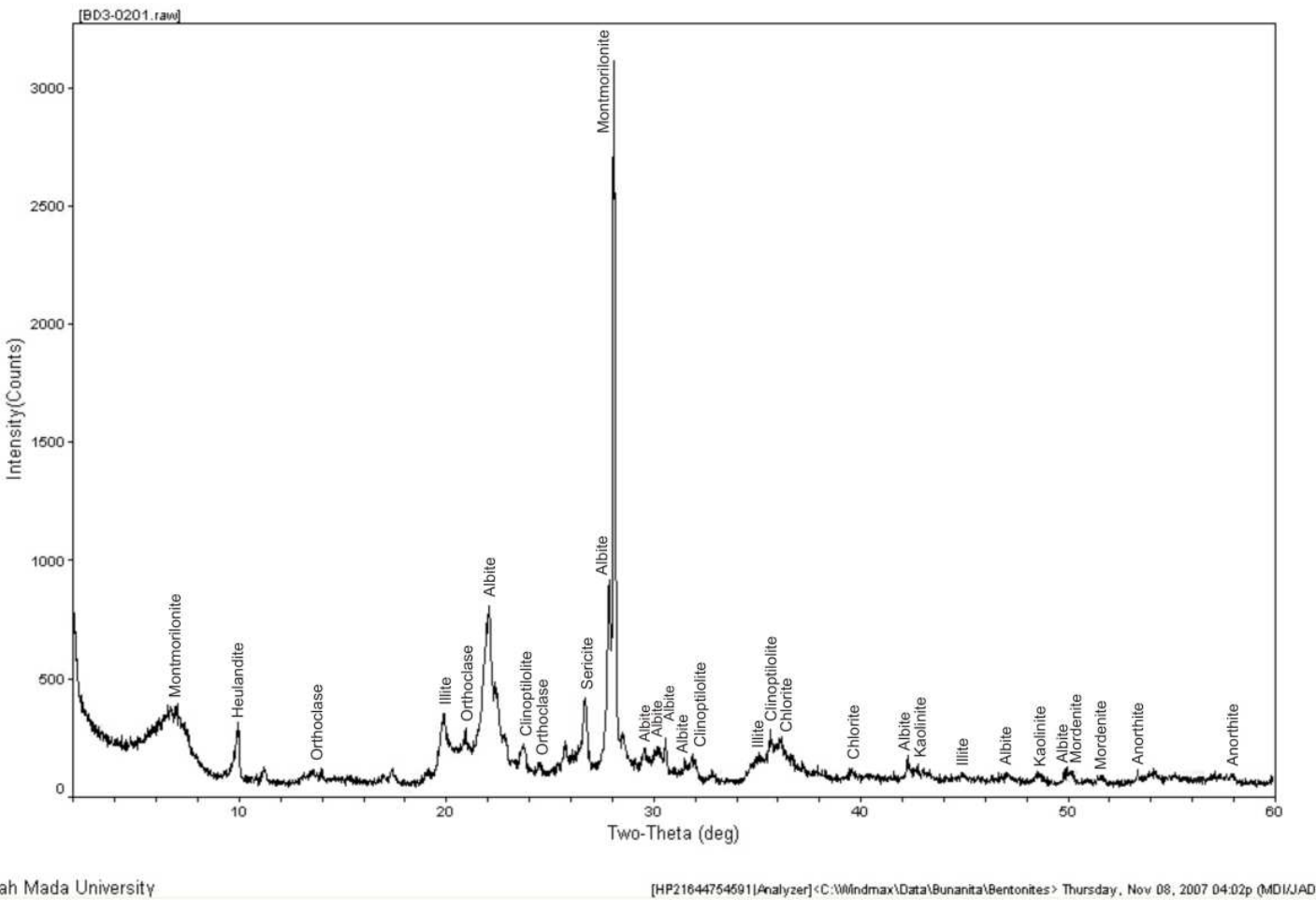

Figure 2: The XRD investigation results of the representative Sidomulyo zeolitic tuff abd the representative Bandung bentonitic tuff. 
3. solution solubility $(\mathrm{pH})$ is known and is remeasured after the experiment

4. particle size $(-100+200$ mesh)

5. ambience temperature $\left(t=25^{\circ} \mathrm{C}\right)$

6. duration needed $(t=24 \mathrm{~h})$

\section{Procedure}

The experiment on groundwater treatment using modified zeolite and bentonite with the method of batch adsorption is done by mixing the considerate amounts of zeolite and bentonite with the solution of heavy-metal concentrations in reaction glasses. Five logarithmic amounts of the modified zeolite and bentonite are chosen: $1 \mathrm{~g}, 2 \mathrm{~g}, 4 \mathrm{~g}, 8 \mathrm{~g}$, and $15 \mathrm{~g}$. These 5 amounts are called five data points to plot a capacity curve or adsorption isotherm of the zeolite and bentonite. Each amount of the modified zeolite and bentonite requires 3-time experiments (for correlations of each data point), done at the same time, leaving 24 hours of mixing time (considered enough to achieve equilibrium conditions) at constant temperature $\left(25^{\circ} \mathrm{C}\right)$, to keep adsorbent (zeolite or bentonite) in suspension (polluted solution zeolite or bentonite) and to allow the ion exchange reaction between the cations $\mathrm{Na}^{+}, \mathrm{K}^{+}, \mathrm{Ca}^{2+}, \mathrm{Mg}^{2+}$ of the modified zeolite and bentonite with the ions $\left(\mathrm{Cd}^{2+}, \mathrm{Cr}^{6+}, \mathrm{Cu}^{2+}, \mathrm{Fe}\right.$, and $\left.\mathrm{Zn}^{2+}\right)$ of heavy metals in solution. After the experiment, all the solutions are re-analyzed by AAS (atomic absorption spectrophotometer) for the rest of heavy metals to figure out the optimum adsorption capacity of zeolite and bentonite. The formula to calculate the cation adsorption capacity (CAC) or the concentrations of heavy metals adsorbed by the modified zeolite or bentonite is expressed below:

$$
C A C=\frac{C_{i}-C_{f}}{C_{f}} \times 100 \text { or } C_{a d s}=C_{i}-C_{f}
$$

where:

$C A C$ : cation exchange capacity (percentage adsorption/extraction)

$C_{a d s}$ : concentration of heavy metal adsorbed by zeolite or bentonite

$C_{i}$ : initial concentration of heavy metal (before the experiment)

$C_{f}$ : final concentration of heavy metal (after the experiment)

Then the data obtained are collected and organized by statistic software SPSS (statistic package for the social science) to make adsorption isotherm in order to easily interpret the adsorption capacity of the modified zeolite and bentonite as well as the heavy metal ions adsorbed by them as shown in an example in Figure 3 .

\section{Discussion}

Though this research hasn't completely finished with all results of analyses as well as the results of the experiment of groundwater treatment, based on the previous researches, the characteristics of the Sidomulyo zeolitic tuff and the Bandung bentonitic tuff can be expected to be composed of clinoptilolite-heulandite, mordenite, montmorillonite, plagioclase, quartz, orthoclase and montmorillonite, clinoptilolite-heulandite, illite, kaolinite, chlorite, quartz, plagioclase, orthoclase, respectively with the evidence of XRD results agreeing with the SEM results of previous studies of Idrus et al., 2006; Idrus et al., 2007; Titisari et al., 2006; and Titisari et al., 2007 showing the zeolite's and bentonite's structural characteristics with the presence of volcanic glasses which are their precursors. Briefly, the zeolitic tuff predominantly contains volcanic glass and clinoptilolite $\left[(\mathrm{Na}, \mathrm{K})_{6}\left(\mathrm{Al}_{6} \mathrm{Si}_{30} \mathrm{O}_{72}\right) \cdot 24 \mathrm{H}_{2} \mathrm{O}\right]$ and the bentonitic tuff abundantly contains volcanic glass and montmorillonite $\left(\mathrm{Na}_{0.33}(\mathrm{Al}, \mathrm{Mg})_{2} \mathrm{Si}_{4} \mathrm{O}_{10}(\mathrm{OH})_{2}\right.$. $\left.\left(\mathrm{H}_{2} \mathrm{O}\right)_{n}\right]$.

Moreover, the same studies also indicated the major oxides of the zeolite and bentonite which play important roles in exchanging with the heavymetal ions of groundwater. This is supported by the works about the utilization of zeolite as adsorbent (Prasetya et al., 2006) and as fertilizer (Idrus et al., 2006; Titisari et al., 2006) and the utilization of bentonite as adsorbent (Vega et al., 2005) and as diarrhea healer (Titisari et al., 2007). The ion exchange capacity of the Sidomulyo zeolitic tuff is 44.4 mgr.eq. $\mathrm{Na}_{2} \mathrm{O} / 100$ gram zeolite and that of the Bandung bentonitic tuff is 20.0 mgr.eq. $\mathrm{Na}_{2} \mathrm{O} / 100$ gram bentonite which will be then increased to 65.3 mgr.eq. $\mathrm{Na}_{2} \mathrm{O} / 100$ gram zeolite and 28.6 mgr.eq. $\mathrm{Na}_{2} \mathrm{O} / 100$ gram bentonite after thermally activated at considerate duration and heat. The results of the adsorption experiment are expected that the zeolite adsorbs the heavy-metal ions faster and more effectively than the bentonite. The more amount of zeolite or bentonite is put into solution of heavy metals, the more concentrations of heavy metals will be expected to be adsorbed. Amongst the five heavy metals in the case study, the selectivity series/sequence of heavy metals for clinoptilolite (zeolite) and montmorillonite (bentonite) in the sodium form will be expected to obtain as follows: $\mathrm{Cd}^{2+}>\mathrm{Cu}^{2+}>\mathrm{Cr}^{6+}>\mathrm{Zn}^{2+}$ (Zamzow et al., 1969). The authors hope that all the results of the research will be used as references for next studies, that the groundwater will be effectively treated by the modified zeolite and bentonite so that the quality of groundwater will be improved for the locals' consumption in the city with no adverse impacts on 


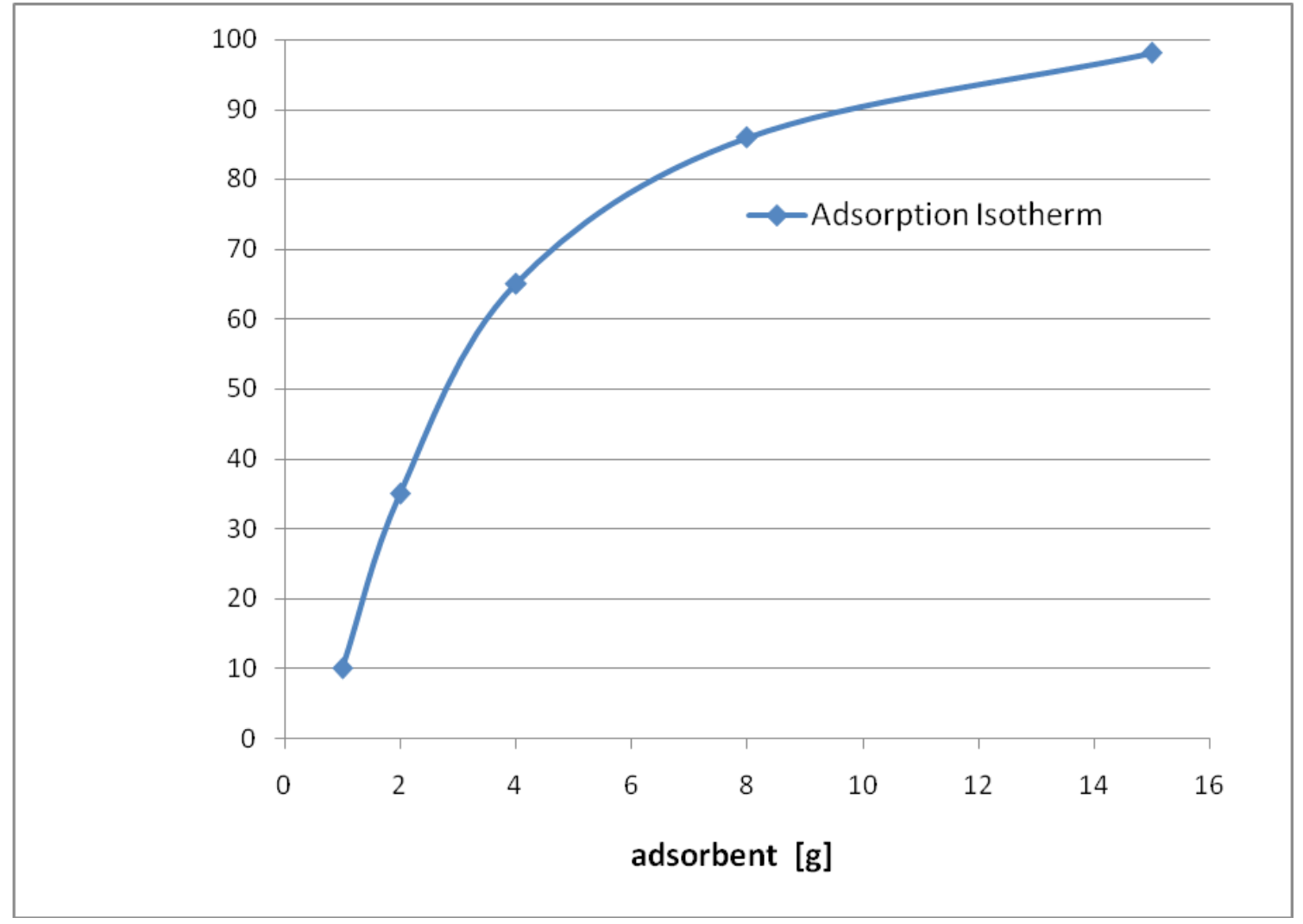

Figure 3: Typical adsorption isotherm of adsorbent (zeolite or bentonite) in terms of heavy-metal ions adsorption capacity (CAC, \%) of adsorbent as a function of adsorbent amount (g). 
health, and the natural zeolite and bentonite will be more commercialized for industries.

\section{Conclusions}

Due to the favorable behaviour of the natural zeolite and bentonite from characterization studies and through thermal activation process to become the modified zeolite and bentonite with the increase in CEC, the Sidomulyo zeolite and the Bandung bentonite are known as good adsorbents for the removal of heavy-metal ions from groundwater. Their natural ion exchange capacities are 44.4 mgr.eq. $\mathrm{Na}_{2} \mathrm{O} / 100$ gram zeolite and 20.0 mgr.eq. $\mathrm{Na}_{2} \mathrm{O} / 100$ gram bentonite which are then increased to 65.3 mgr.eq. $\mathrm{Na}_{2} \mathrm{O} / 100$ gram zeolite and 28.6 mgr.eq. $\mathrm{Na}_{2} \mathrm{O} / 100$ gram bentonite, respectively. Because of its multi-porous structure, zeolite is considered more effective and faster than bentonite in adsorption process. This is referenced by several previous studies like Prasetya et al., 2006; Idrus et al., 2006; Titisari et al., 2006; Vega et al., 2005; Titisari et al., 2007. As expectation for the results of the adsorption experiment, the more amount of zeolite or bentonite is put into solution of heavy metals, the more concentrations of heavy metals will be adsorbed and the selectivity sequence of heavy metals for clinoptilolite and montmorillonite will be as follows: $\mathrm{Cd}^{2+}>\mathrm{Cu}^{2+}>\mathrm{Cr}^{6+}>\mathrm{Zn}^{2+}$ (Zamzow et al., 1969), and at last, the groundwater is hoped to be treated and the zeolite and bentonite will be known even more useful for groundwater treatment.

\section{Acknowledgements}

The authors are thankful to the Japanese International Cooperation Agency (JICA) who funded the ASEAN University Network/Southeast Asia Engineering Education Development Network (AUN/SEED-Net) Program. Our thanks also go to Anita Yuliyanti for her cooperative assistance on the fieldwork and the laboratory work.

\section{References}

Genevraye, P., de and Samuel, L., 1972, Geology of the Kendeng Zone (Central and East Java), Proceedings of the First Indonesian Petroleum Association Annual Convention, Jakarta

Keophousone, P., 2007, Assessment of Groundwater Contaminant Loading Potential for Yogyakarta Urban Area, Thesis, Geological Engineering Department, Faculty of Engineering, Gadjah Mada University, Yogyakarta.

Huyen, D.T., 2007, Groundwater Modeling in Yogyakarta Urban Area, Thesis, Geological Engineering Department, Faculty of Engineering, Gadjah Mada University, Yogyakarta.
Idrus, A., Titisari, A.D., Sudiyo, R., and Soekrisno, R., 2006, Development of A Zeolites-Based Industry Through and Integrated Study on Characterization Quality Improvement and Utilization as Additive Fertilizer Materials of Natural Zeolite Deposits from Yogyakarta, Indonesia, Proceedings of Final Report of Hi-Link Project Research, Gadjah Mada University, Yogyakarta, Indonesia.

Idrus, A., Titisari, A.D., and Kurniawan, A.P., 2007, Characteristics, Quality Improvement and Exploitation of Zeolitic Tuff of the Sidomulyo Area, Gunung Kidul Regency, Yogyakarta Special Province, Proceedings Joint Convention Bali 2007, The 32nd HAGI and The 36th IAGI Annual Convention and Exhibition, Bali, Indonesia.

Marks, P., 1957, Stratigraphic Lexicon of Indonesia, Publikasi Keilmuan no 31, Seri Geologi, Pusat Djawatan Geologi, Kementrian Perekonomian R.I. Bandung, 233 p.

Prasetya, A., Purnomo, C.W., and Rifai, A., 2006, In-Situ Heavy Metal Contained Wastewater Remediation of Small and Medium Scale Industries (SMIs) Using Natural Zeolite and Modified Fly Ash Compound, Proceedings of Final Report of Hi-Link Project Research, Gadjah Mada University, Yogyakarta, Indonesia.

Raksmey, R., 2007, Groundwater Vulnerability Assessment in Yogyakarta Urban Area, Thesis, Geological Engineering Department, Faculty of Engineering, Gadjah Mada University, Yogyakarta

Soeria-Atmadja, R., Maury, R.C., Bellon, H., Pringgoprawiro, H. Polve, M., and Priadi, B., 1991, The Tertiary Magmatic Belt in Java, Proceedings of Symposium in the Dynamic of Subduction and Its Products, Research and Development Center of Geo-technology, Indonesia Institute of Science (LIPI), Bandung, pp. 98-121.

Suwasti, 2005, Geology of Wonosegoro, Boyolali Regency, Central Java, Indonesia, Geological Mapping Report, Geological Engineering Department, Gadjah Mada University, unpublished.

Titisari, A.D., Idrus, A., and Widiasmoro, 2006, Mineralogical Characteristics of the Sampang Zeolitic Tuff, Gunungkidul-Indonesia, and its Utilization as Fertilizer, 4th International Workshop on Earth Science and Technology, 4-5 December 2006, Kyushu University, Japan.

Titisari, A.D., and Widiasmoro, 2006, Mineralogical Characteristics of the Kedungbedah Bentonite, Boyolali, Indonesia, Proceedings of The 8th Field Wise Seminar on Geological Engineering Field and The 3rd International Symposium \& Exhibition on Earth Resources and Geological Engineering Education, Gadjah Mada University, Yogyakarta, Indonesia, p. 309-315.

Titisari, A.D., Widiasmoro, and Idrus, A., 2007, The Characteristics and Quality of Kedungbedah Bentonite at Wonosegoro Area, Boyolali Regency, Central Java and its Utilization for Healing (Anti-Diarrhea), Proceedings of Joint Convention Bali 2007, The 32nd HAGI and The 36th IAGI Annual Convention and Exhibition, Bali, Indonesia.

van Bemmelen, R.W., 1970, The Geology of Indonesia: General Geology of Indonesia and Adjacent Archipela- 
goes, 2nd ed., Vol. 1A, Martinus Nijhoff, The Haque, $732 \mathrm{p}$.

Vega, J.L., Ayala, J., Loredo, J., and Garcia Iglesias, J., 2005, Bentonite as Adsorbent of Heavy Metals Ions from Mine Waste Leachates: Experimental Data, 9th Inter- national Mine Water Association Congress (IMWAC), Oviedo, Spain, pp. 603-609.

Zamzow, M.J. and Murphy, J.E., 1992, Removal of metal cations from water using zeolites, Separation Science and Technology 27 14, pp. 1969-1984. 